\title{
Determination of Submerged Breakwater Location for Coastal Protection in Panjang Island Waters Jepara
}

\author{
Denny Nugroho Sugianto ${ }^{1,2, *}$, Purwanto ${ }^{1}$, Gentur Handoyo ${ }^{1}$, Aulia Oktaviani $^{1}$, Kunarso $^{1}$, Muhammad Zainuri $^{1}$, Agus Indarjo $^{2,3}$ \\ ${ }^{1}$ Oceanography Department, Faculty of Fisheries and Marine Sciences, Diponegoro University Indonesia, Tembalang Semarang, \\ Indonesia 50275
}

${ }^{2}$ Center for Coastal Disaster Mitigation and Rehabilitation Studies, Diponegoro University, Jl. Prof. Soedarto SH Tembalang, Semarang 50275 Indonesia Indonesia

${ }^{3}$ Marine Science Department, Diponegoro University, Indonesia

\begin{tabular}{l} 
A R T I C L E I N F O \\
\hline Article history: \\
Received: 26 July, 2019 \\
Accepted: 08 September, 2019 \\
Online: 22 October, 2019 \\
\hline Keywords: \\
Submerged breakwater \\
ocean wave \\
Jepara \\
coastal protection \\
mitigation
\end{tabular}

\begin{tabular}{l} 
A B S T R A C T \\
\hline Panjang Island is one of the islands which is categorized as a small island and is located \\
in Jepara District, Jepara Regency, Central Java Province. The problem faced by Panjang \\
Island is erosion, which increasingly erodes the shoreline and begins to damage buildings \\
on the beach. A solution that is effective enough to overcome erosion or changes in the \\
coastline is to build coastal shelters to reduce wave energy and increase sediment supply. \\
The purpose of this study is to study the exact location of the submerged breakwater from \\
aspects of wave parameters. The method used is wave forecasting and numerical wave \\
model scenarios for submerged breakwater structures. The results showed wave height \\
forecasting results in the western season (December, January, and February) is 2.66 \\
meters, in the first transition season (March, April, May) is 2.14 meters, at east season \\
(September, October, December) 1.45 meters, in the second transition season (June, July, \\
August) is 2.26 meters. The model simulation results with a scenario based on the plan \\
show the most effective damping in the east season with a reduction of 52.26\%.
\end{tabular}

\section{Introduction}

Panjang Island is one of the islands which is categorized as a small island and is located in Ujung Batu Village, Jepara District, Jepara Regency, Central Java Province. Panjang Island is surrounded by shallow sea and is located on the west side of Kartini Beach, Jepara with a distance of approximately 1.5 nautical miles. Ecosystems in Panjang Island waters are coral reefs, seagrass beds and mangroves with the substrate in the form of sand, mud and coral fragments, making Panjang Island as one of the marine tourism areas in Jepara.

The problem faced by Panjang Island is erosion, which increasingly erodes the shoreline and begins to damage buildings on the beach. This erosion is caused by hydro oceanographic factors, one of which is waves. Waves usually spread from the high seas to the beach. Waves can cause energy that can give effect to the formation of the coast because waves can cause

*Denny Nugroho Sugianto, Oceanography Department, Diponegoro University Indonesia, dennysugianto.oceanography@gmail.com

www.astesj.com

https://dx.doi.org/10.25046/aj040545 currents in a direction perpendicular to the coast and along the coast causing sediment transport [1]. Ocean waves are oscillatory movements of water that occur due to the influence of wind, earthquakes, submarine volcanoes, avalanches, and human activities [2]. According to Dijkstra [3], ocean waves are one of the parameters that influence changes in coastal and marine areas in addition to currents and tides. So it is necessary to study ocean waves for the optimal management and development potential of coastal areas.

The Panjang Island beach protection effort is by building a breakwater. Separate breakwater system is designed to reflect, eliminate, refract and decompose waves, resulting in lower energy in the structure [1] thus limiting storm damage and long-term erosion. Sinking breakwaters can be classified into 3 (three) categories, namely: dynamically stable reef breakwater, statically stable low-crested breakwater and statically stable submerged breakwater [4]. The use of submerged breakwaters, including lately submerged breakwaters, has been widely used [5]. Technological adaptation, especially to offshore breakwater 
structures, has resulted in sinking offshore breakwater structures that are now known as Low-Crested Breakwaters (LCB) or submerged breakwater. Some literature listens to the widespread use of LCB in various countries such as the USA, UK, Japan and Italy [6], even in Japan the use of LCB became very popular and more widely used than conventional breakwaters [7]. The advantages of submerged breakwater include being able to reduce the aesthetic impact, cheaper, better water circulation that allows for improved water quality and biological productivity and reduces the effect of barriers to sediment transport [8]. The construction of submerged breakwater structures on Panjang Island is an attempt to maintain the beauty of the coast from the construction of a breakwater built on water and to reduce wave energy that erodes the shoreline. With the construction of a submerged breakwater, it is hoped that the coastal area will remain beautiful and this building will be able to become the initial stage of building breakwater naturally with the hope of coral growth in the building. Therefore, it is deemed necessary to conduct a study related to wave attenuation through an underwater structure.

In the study of determining the location of the submerged breakwater, it examined the exact location for placement of submerged breakwater based on wave values and depth. So that it can be seen the most effective location for placement of submerged breakwater so that that wave energy can be reduced to the maximum in order to overcome erosion that occurs in the coastline of Panjang Island waters

\section{Methods}

The material in this study consisted of two types of data, namely the main data namely wave measurement data and wave model data in the form of wave height $(\mathrm{H})$ and wave period $(\mathrm{T})$. The supporting data used in this study consisted of tidal data BMKG Maritime Semarang in October 2017; bathymetry data of Panjang Island Waters, Jepara Regency survey results using
Echosounder; Indonesian earth map that was issued by Badan Koordinasi Survey dan Pemetaan Nasional (BAKOSURTANAL) in 2000 Sheets 1409 - 04 and Sheets 1409 - 05; Google Earth map Image of GeoEye Satellite scale of 2017; three-hour daily wind data for 11 years (2007-2017) obtained from www.ogimet.com.

The survey was conducted in October 2017 on Panjang Island waters. The sample location was determined by purposive sampling method, and the measurement of wave data was carried out using the SonTek Argonaut-XR ADCP at a depth of 11 meters below sea level. The collection of wave data is carried out for five days with the interval of taking wave data every 10 minutes. The bathymetric contour data used in this study is data obtained from direct surveys using the Garmin 585 Echosounder and scale stick. Tidal data used is tidal data obtained from the Meteorology, Climatology and Geophysics Station (BMKG) Semarang. The wind data used in this study are three-hour intervals of wind data obtained from the website www.ogimet.com, which is then carried out by wave forecasting Sugianto et al. [9]. Wave modelling consists of simulated wave propagation analysis on the mathematical model.

Data processing is done in the form of wind data processing and modelling. Wind data is needed to do wave forecasting. Wave forecasting used in the research is the wave forecasting method Sugianto et al. [9]. Calculation of wave height and significant wave period is calculated using calculations:

For wind speeds starting from $\mathrm{U}>0$ knots

$$
\mathrm{Hs}=0,0016 \mathrm{U} 2+0,0406 \mathrm{U}
$$

For wind speeds starting from $\mathrm{U}>0$ knots

$$
\text { Ts }=0,15 \mathrm{U}+2,892
$$

Where

Hs: Significant wave height (meters)

Ts: Significant wave period (seconds)

$\mathrm{U}$ : Wind speed (knots)

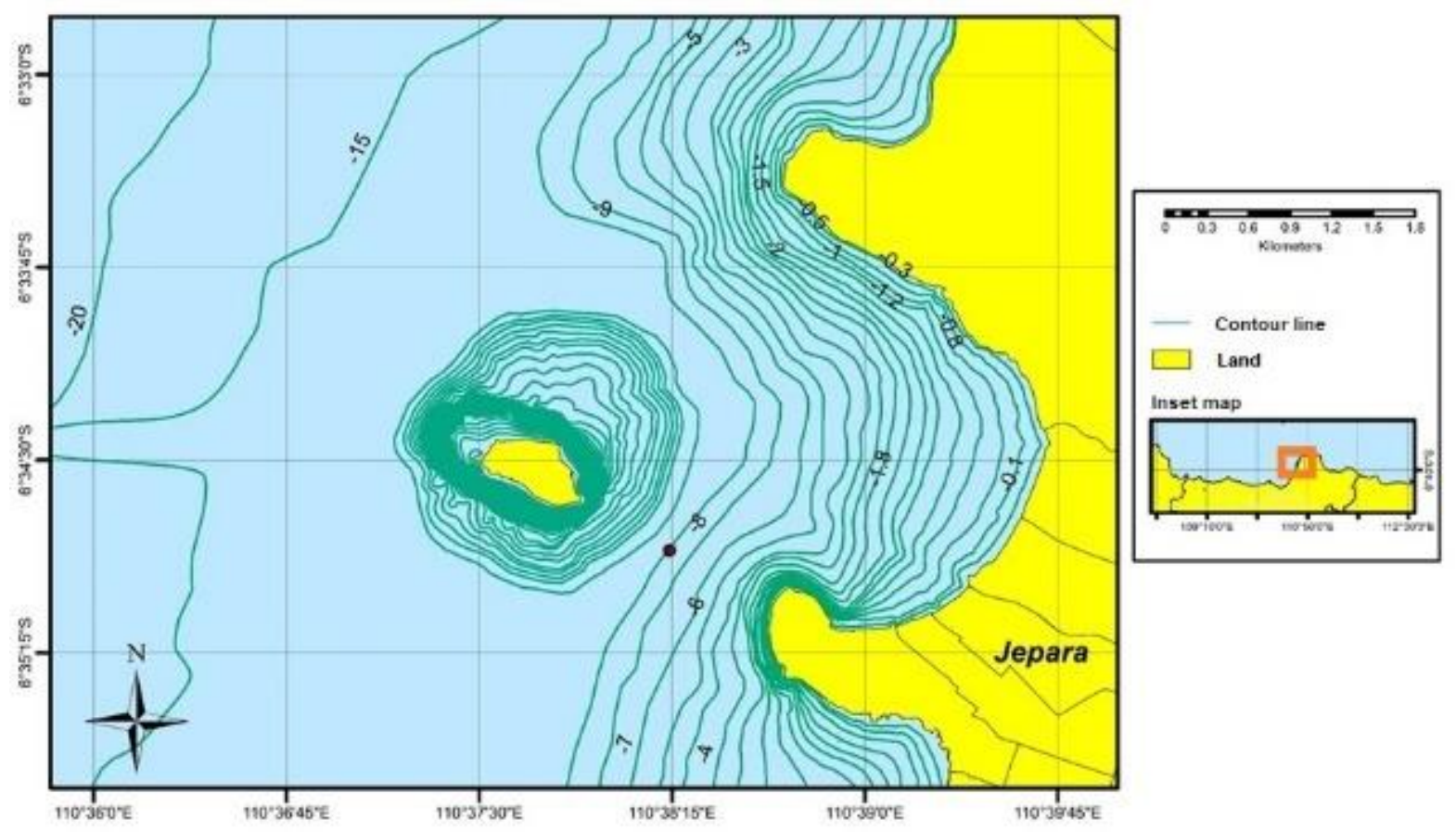

Figure 1. Research Site in Panjang Island waters, Jepara 
Wave data from observations were analyzed by the method of determining representative waves using the values of Hmax and Tmax. The beach building consists of 4 modules with a gap of 10 meters per module. It is placed at a depth of 3.5 meters with a building height of $75 \%$ from a depth of 2.5 meters based on the calculation of breaking waves in the east season. The wave parameter data used as input to the model is wave data forecasting results with the DNS method per season. The wave parameter data is in the form of wave height $(\mathrm{H})$ and wave period $(\mathrm{T})$ and the dominant direction of the wind is blowing.

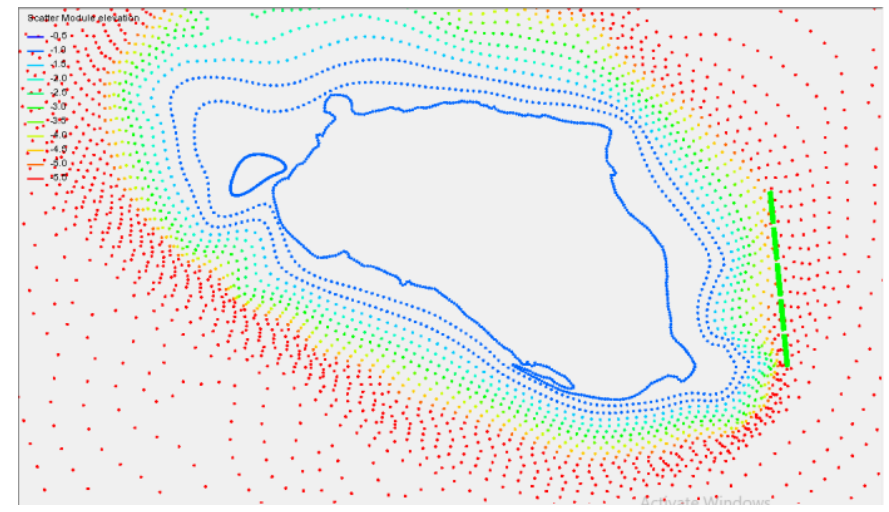

Figure: 2 Submerged breakwater experiment layout.

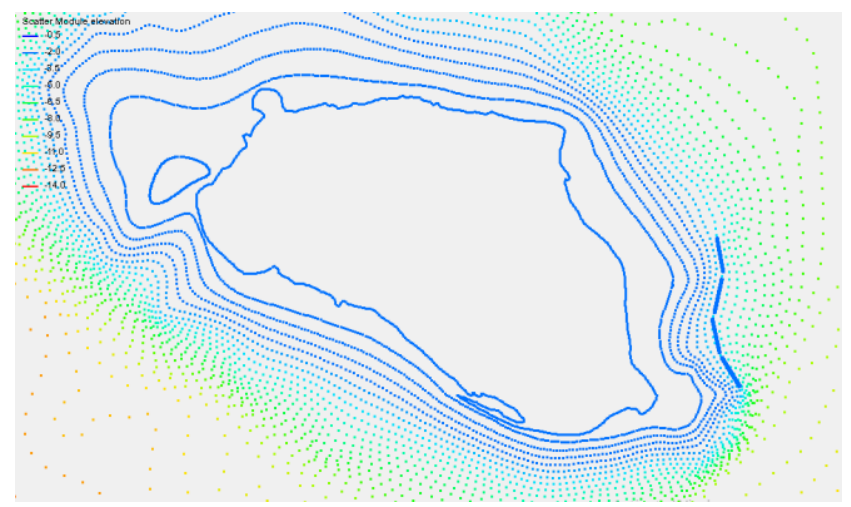

Figure 3: Selected submerged breakwater layout.

Table 1. Seasonal wave parameters as input model for existing model area in Panjang Island waters, Jepara

\begin{tabular}{llll}
\hline Season & $\begin{array}{l}\text { Wave } \\
\text { Height } \\
(\mathrm{m})\end{array}$ & $\begin{array}{l}\text { Wave } \\
\text { Period } \\
(\mathrm{s})\end{array}$ & $\begin{array}{l}\text { Direction } \\
\left({ }^{\circ}\right)\end{array}$ \\
\hline West (Dec, Jan, Feb) & 2.66 & 7.39 & 315 \\
$\begin{array}{l}\text { East (Sept, Oct, Nov) } \\
\text { Transition 1 }\end{array}$ & 2.13 & 6.79 & 45 \\
$\begin{array}{l}\text { (March, April, May) } \\
\text { Transition 2 } \\
\text { (June, July, August) }\end{array}$ & 2.26 & 6.94 & 0 \\
\hline
\end{tabular}

According to Holthuijsen [10], waves generated by wind have a wave period of fewer than 30 seconds. The wave model simulation is generated from the output of the wave tracking step which is then carried out in the loop film step with the results in the form of wave tracking videos in the 3-dimensional form shown in Figure 4.
Table 2. Seasonal wave parameters as input for small models

\begin{tabular}{llll}
\hline Season & $\begin{array}{l}\text { Wave } \\
\text { Height } \\
(\mathrm{m})\end{array}$ & $\begin{array}{l}\text { Wave } \\
\text { Period } \\
(\mathrm{s})\end{array}$ & $\begin{array}{l}\text { Direction } \\
\left({ }^{\circ}\right)\end{array}$ \\
\hline $\begin{array}{l}\text { West (Dec, Jan, Feb) } \\
\text { East (Sept, Oct, Nov) }\end{array}$ & 1.3 & 8.1 & 315 \\
$\begin{array}{l}\text { Transition 1 } \\
\text { (March, April, May) }\end{array}$ & 1.03 & 6.98 & $45 \& 90$ \\
$\begin{array}{l}\text { Transition 2 } \\
\text { (June, July, August) }\end{array}$ & 1.3 & 8.1 & 0 \\
\hline
\end{tabular}

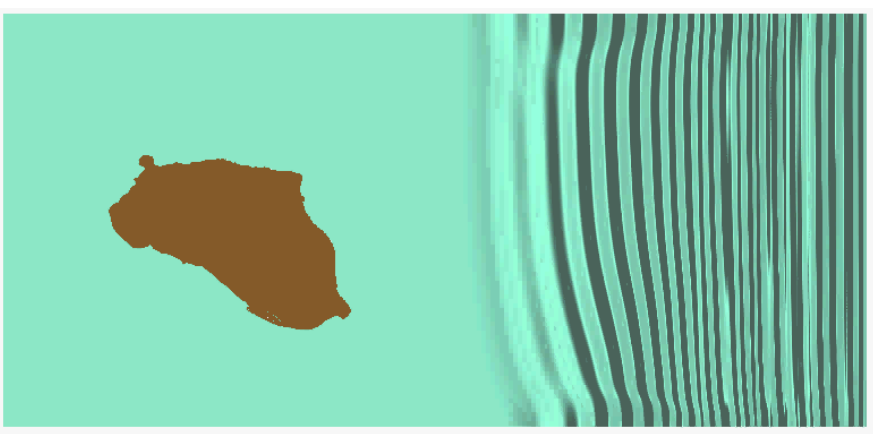

Figure 4 Simulation of the wave model of the east season with the coming direction of waves from the east.

\section{Result}

\subsection{Measurement of Wave Results at The Study Site}

Wave data retrieval was carried out at Panjang Island waters, Jepara, Central Java with the coordinates of $110^{\circ} 37$ '59.52 "BT and $6^{\circ} 34^{\prime} 44.15^{\prime \prime} \mathrm{LS}$ at a depth of 11 meters. The time of data collection is carried out for five days from October 4, 2017, to October 8, 2017. The results of wave measurements are in the form of wave height and wave period, which can be seen in the following table.

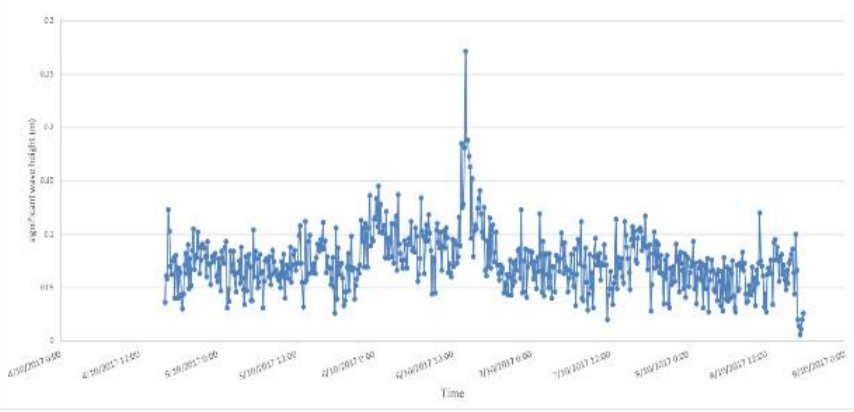

Figure. 5 Graph of significant waves high in measuring on Panjang Island Waters

Table 3. Description of significant high wave statistics measurement at Panjang Island Waters

\begin{tabular}{lll}
\hline \multicolumn{2}{l}{ Descriptive (Amount of Data, $\mathrm{N}=599)$} & $\mathrm{Hs}(\mathrm{m})$ \\
\hline \multirow{3}{*}{ Wave } & Average & 0,0700 \\
Height & Minimum & 0.0060 \\
& Maximum & 0.2710 \\
& Range & 0.0738 \\
& Skewness & 1.3650 \\
\hline
\end{tabular}




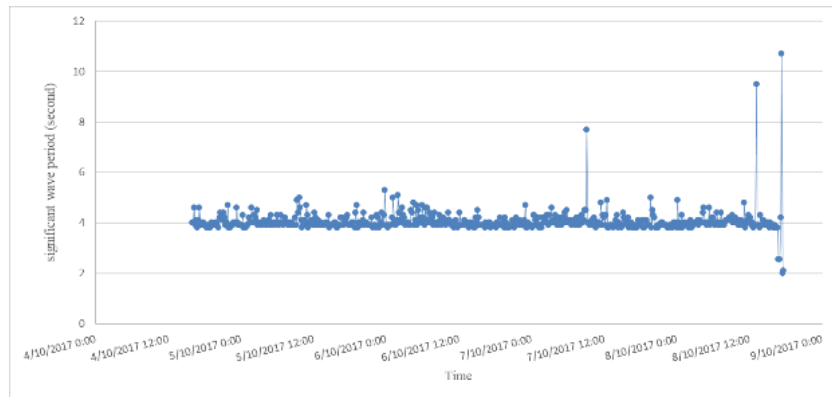

Figure. 6 Significant wave period charts measurement on Panjang Island Waters

Table 4. Descriptive statistics of significant period periods measurement at Panjang Island Waters

\begin{tabular}{lll}
\hline Descriptive (Amount of Data, N = 599) & Ts (s) \\
\hline \multirow{4}{*}{ Wave Period } & Average & 3.567 \\
& Minimum & 2.000 \\
& Maximum & 10.70 \\
& Range & 8.700 \\
& Skewness & 2.863 \\
\hline
\end{tabular}

Define abbreviations and acronyms the first time they are used in the text, even after they have been defined in the abstract. Do not use abbreviations in the title or heads unless they are unavoidable.

\subsection{Simulation of Submerged Breakwater Wave Model on \\ Panjang Island Waters, Jepara}

Based on the results of calculations carried out, the waters of Panjang Island Jepara according to their relative depth, $d / L$ of 0.105 so that these waters are included in the category of transitional waves or medium water waves. This calculation is based on the statement of Triatmodjo [11] which states that medium water waves have a relative depth between $0.05<\mathrm{d} / \mathrm{L}$ $<0.5$.

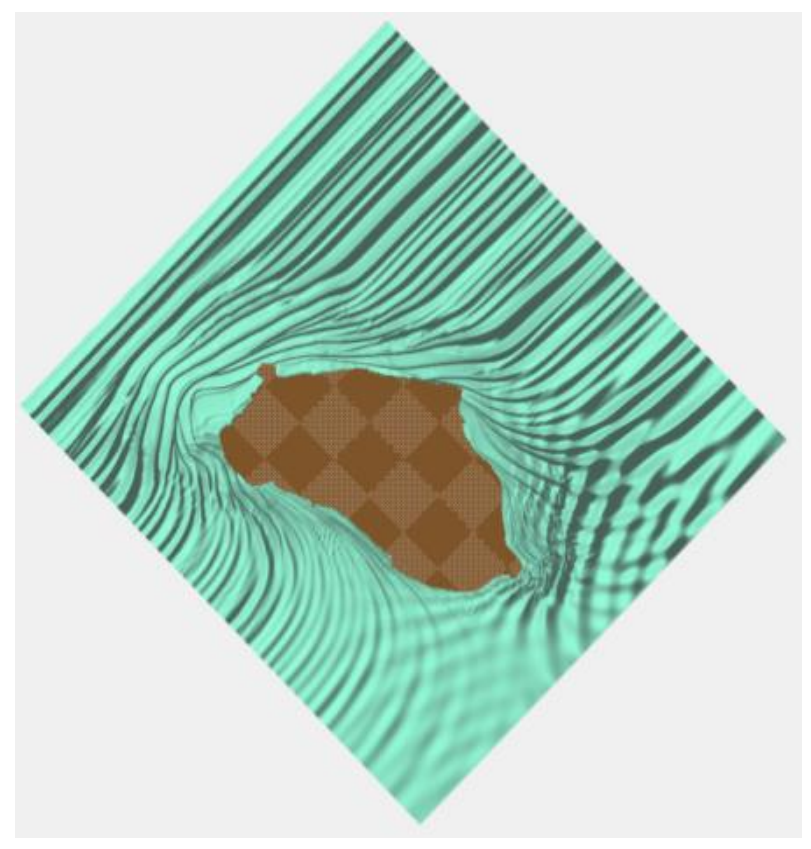

Figure 7. Propagation of Submerged Breakwater Wave Models in the West Season in Panjang Island Waters, Jepara

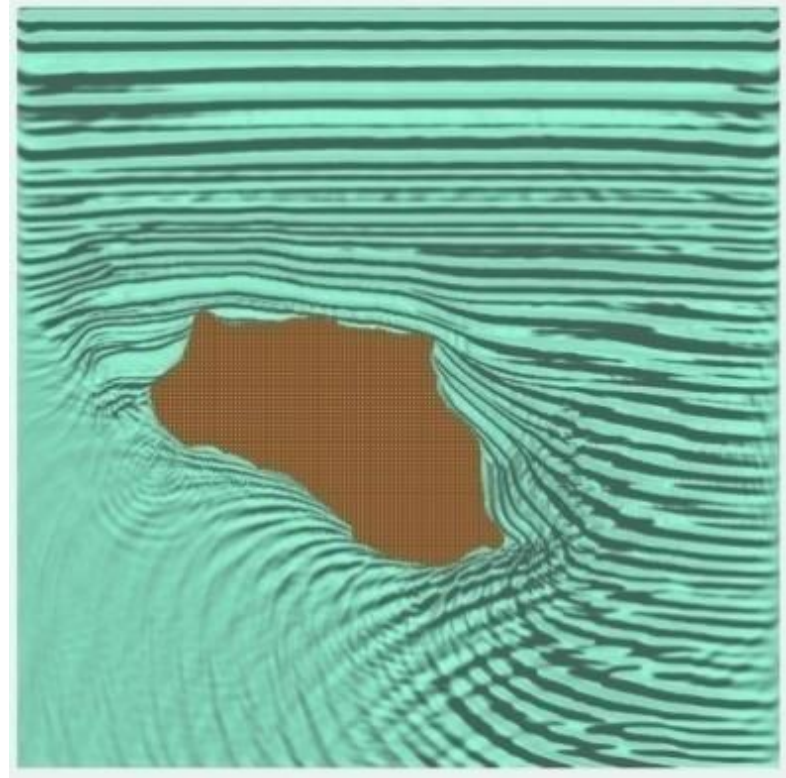

Figure 8. Propagation of Submerged Breakwater Wave Models in the first transition season in Panjang Island Waters, Jepara.

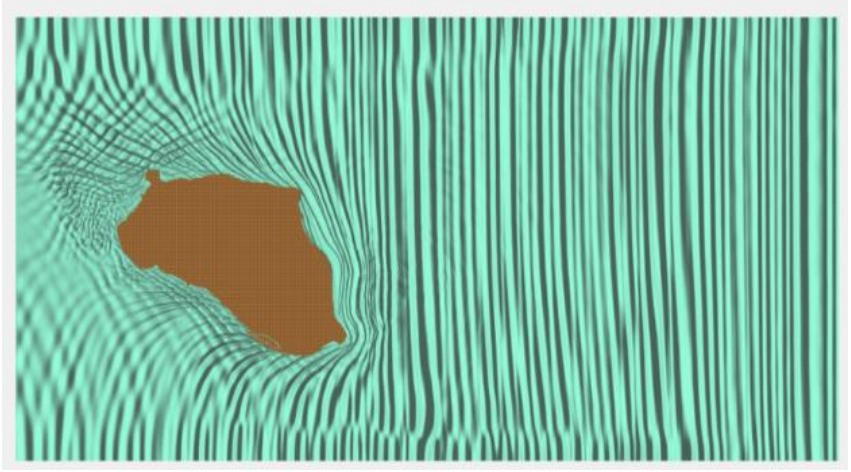

Figure 9. Propagation of Submerged Breakwater Wave Models in the East Season from The East $\left(90^{\circ}\right)$ in Panjang Island Waters, Jepara.

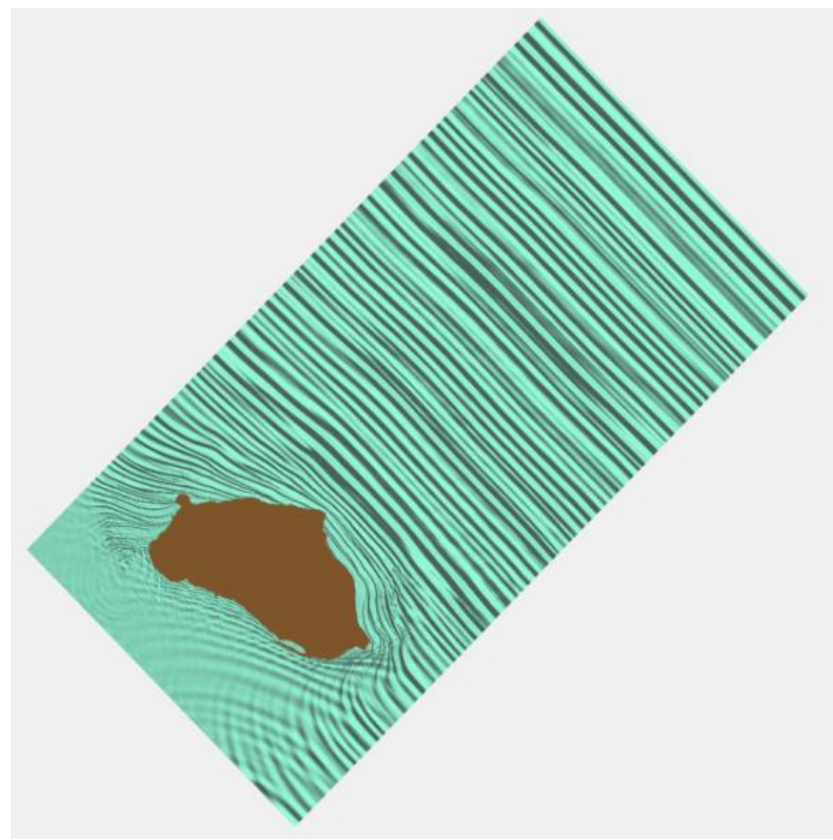

Figure 10. Propagation of Submerged Breakwater Wave Models in the East Season from the Northeast $\left(45^{\circ}\right)$ in Panjang Island Waters, Jepara. 
Method to calculate the effectiveness of submerged breakwater is by comparing wave height before and after the construction of the submerged breakwater. The difference in value after compared is then made into percent.

Table 5. Submerged breakwater building efficiency in Panjang Island waters, Jepara (December, January, February)

\begin{tabular}{|c|c|c|c|}
\hline \multirow{2}{*}{ Scheme } & \multicolumn{3}{|c|}{ Wave Height (m) } \\
\hline & Point A & Point B & Point $\mathrm{C}$ \\
\hline $\begin{array}{l}\text { Before the } \\
\text { construction of } \\
\text { the submerged } \\
\text { breakwater }\end{array}$ & $1.028 \mathrm{~m}$ & $0.77 \mathrm{~m}$ & $0.7 \mathrm{~m}$ \\
\hline $\begin{array}{l}\text { After the } \\
\text { construction of } \\
\text { the submerged } \\
\text { breakwater }\end{array}$ & $0.56 \mathrm{~m}$ & $0.4 \mathrm{~m}$ & $0.5 \mathrm{~m}$ \\
\hline $\begin{array}{l}\text { Effectiveness } \\
\text { Value }(\%)\end{array}$ & 45.5 & 48 & 28.5 \\
\hline Average (\%) & & 40.7 & \\
\hline
\end{tabular}

Table 6. Submerged breakwater building efficiency in Panjang Island waters, Jepara (March until August)

\begin{tabular}{llll}
\hline \multirow{2}{*}{ Scheme } & \multicolumn{3}{c}{ Wave Height $(\mathrm{m})$} \\
\cline { 2 - 4 } & Point A & Point B & Point C \\
\hline $\begin{array}{l}\text { Before the } \\
\text { construction of } \\
\text { the submerged } \\
\text { breakwater }\end{array}$ & $2.098 \mathrm{~m}$ & $2.06 \mathrm{~m}$ & $2.1 \mathrm{~m}$ \\
\hline $\begin{array}{l}\text { After the } \\
\text { construction of } \\
\text { the submerged } \\
\text { breakwater }\end{array}$ & $1.787 \mathrm{~m}$ & $1.7 \mathrm{~m}$ & $1.73 \mathrm{~m}$ \\
\hline $\begin{array}{l}\text { Effectiveness } \\
\text { Value (\%) }\end{array}$ & 14.82 & 17.47 & 17.6 \\
\hline Average $(\%)$ & \multicolumn{3}{|c}{16.63} \\
\hline
\end{tabular}

Table 7. Submerged breakwater building efficiency in Panjang Island waters, Jepara (September, October, December) from the east $\left(90^{\circ}\right)$

\begin{tabular}{llll}
\hline \multirow{2}{*}{ Scheme } & \multicolumn{3}{c}{ Wave Height (m) } \\
\cline { 2 - 4 } & Point A & Point B & Point C \\
\hline $\begin{array}{l}\text { Before the } \\
\text { construction of } \\
\text { the submerged } \\
\text { breakwater }\end{array}$ & $1.52 \mathrm{~m}$ & $1.739 \mathrm{~m}$ & $1.65 \mathrm{~m}$ \\
\hline $\begin{array}{l}\text { After the } \\
\text { construction of } \\
\text { the submerged } \\
\text { breakwater }\end{array}$ & $0.83 \mathrm{~m}$ & $0.74 \mathrm{~m}$ & $0.76 \mathrm{~m}$ \\
\hline $\begin{array}{l}\text { Effectiveness } \\
\text { Value (\%) }\end{array}$ & 45.4 & 57.45 & 53.94 \\
\hline Average (\%) & & 52.26 & \\
\hline
\end{tabular}

Based on the value of maximum wave height and wave period, it is then used to calculate the wave breakdown parameters in Panjang Island waters, Jepara. Based on the calculations that have been done, the breaking wave height is 0.54 meters with the www.astesj.com depth of the breaking wave at 0.59 meters. The breaking wave is relatively small due to the influence of wave data collection time in October where the month is included in the Transition II season where the wind strength is relatively small.

Wind data obtained from www.ogimet.com for 11 years is displayed in the form of wind roses or windrose. It can be seen from the results that the relative velocity of the biggest winds in the western season. East and transition 1 and transition 2 are relatively small, with the dominant direction coming from the south, while the south is from the land so it is not used in wave forecasting because it cannot generate waves at sea.

Table 8. Submerged breakwater building efficiency in Panjang Island waters, Jepara (September, October, December) from the northeast $\left(45^{\circ}\right)$

\begin{tabular}{llcl}
\hline \multirow{2}{*}{ Scheme } & \multicolumn{3}{c}{ Wave Height $(\mathrm{m})$} \\
\cline { 2 - 3 } & Point A & Point B & Point C \\
\hline $\begin{array}{l}\text { Before the } \\
\text { construction of } \\
\text { the submerged } \\
\text { breakwater }\end{array}$ & $1.74 \mathrm{~m}$ & $1.73 \mathrm{~m}$ & $1.65 \mathrm{~m}$ \\
\hline $\begin{array}{l}\text { After the } \\
\text { construction of } \\
\text { the submerged } \\
\text { breakwater }\end{array}$ & $1.01 \mathrm{~m}$ & $0.947 \mathrm{~m}$ & $0.9 \mathrm{~m}$ \\
\hline $\begin{array}{l}\text { Effectiveness } \\
\text { Value }(\%)\end{array}$ & 41.95 & 45.26 & 45.45 \\
\hline Average $(\%)$ & \multicolumn{3}{c}{44.22} \\
\hline
\end{tabular}

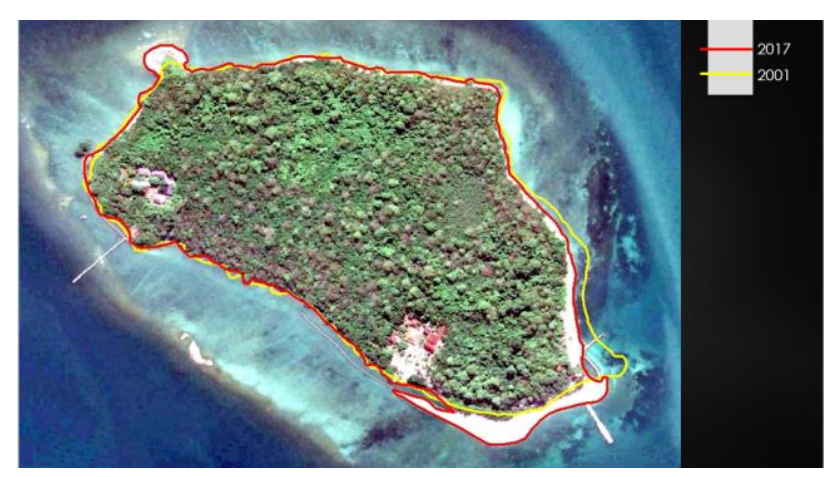

Figure 11. Erosion in Panjang Island, Jepara calculated by GIS data.

The location and dimensions of the submerged breakwater are based on the most vulnerable locations affected by erosion, namely on the east side of Panjang Island waters, Jepara. Then the calculation of the breaking wave plan was then carried out. According to Triatmodjo [11], a wave that moves from the deep sea with a wave height greater than $\mathrm{H} 0$ will break at a distance greater than Xp in front of the building. While if the wave height in the deep sea is smaller than $\mathrm{HO}$ it will break in buildings with a height that is smaller than the planned wave height. Calculation of building dimensions is also based on HHWL sea level, so that the construction of a submerged breakwater is effective at the highest sea level and does not appear when the water level is lowest.

Based on the simulation results of wave propagation models on the submerged breakwater in Panjang Island waters, Jepara, it was found that submerged breakwater buildings played a role in 
dampening waves in these waters, where waves were seen refraction and the wave height was reduced by about 0.7 meters.

Ocean waves are the parameters of marine hydraulics that have the most role in controlling the process of coastal dynamics and changes in the back and forth of coastlines. When the wave is large, the force and the blow energy will be large too. Broken waves are closely related to transport and distribution of sediments along the coast. The coast will experience erosion as indicated by the retreat of the coastline from its original position. This erosion process occurs when there is no balance between supply and capacity of sediment transport.

Looking at the very small efficiency in the transition season and the western season this is because the building structure is concentrated in the eastern season where the east side of the island has the worst erosion. Even though the north and west sides are the side which is directly affected by the high waves that are generated by wind from wider waters. However, the worst erosion occurred on the east side of the island. This is due to the influence of other oceanographic hydro, namely ocean currents. Ocean currents in the waters of Panjang Jepara Island according to Al Ghifari [12] is a type of tidal flow. There are unique conditions in the waters between the cape in the Bulu and Panjang Island Kelurahan, which is a narrow topography that causes a greater current velocity than the surroundings. A large mass of water moving in space which gets smaller will cause the current to move faster. Hydro-oceanographic conditions such as ocean currents have a direct influence on sediment transport around the coast and cause the worst erosion not on parts of the island facing directly to wider waters on the north and west but on the east side where there is a narrow gap between Panjang Island and Tanjung in around the Port of Kartini which causes a greater current speed than the surroundings.

So that the greatest effectiveness in the east season is $52.26 \%$. Where buildings are effective enough to dampen incoming waves, although the damping is rather small, the reason why submerged breakwater is built is an aesthetic reason, so that the aesthetic of the beach is maintained. This is because Panjang Island, Jepara is a tourist destination in Jepara Regency as well as a place of pilgrimage for tourists. So that protection remains carried out and does not interfere with the beauty offered on Panjang Island as a tourist destination in Jepara Regency.

\section{Conclusion}

The characteristics of sea waves in the waters of Panjang Island, Jepara include the types of swell/sea waves, namely waves that are generated by distant winds. While based on the period, including the type of gravitational waves (period $1 \mathrm{sec}-30 \mathrm{sec}$ ). Sea waves in Panjang Island waters, Jepara according to their relative depth, $\mathrm{d} / \mathrm{L}$ of 0.105 so that these waters are included in the category of transitional waves or medium water waves. Wave transformations that occur due to the influence of changes in depth with coefficient Ks of 0.989 and wave refraction process with $\mathrm{Kr}$ coefficient of 0.88 . While the $\mathrm{Hb}$ breaking wave height is $0.54 \mathrm{~m}$ with a db breaking wave depth of $0.58 \mathrm{~m}$. The effectiveness of the breakwater design in submerged breakwater buildings can reduce waves by an average of $52.26 \%$ in the east season. The most important consideration is the placement of submerged breakwater buildings on the east side of Panjang Island waters, Jepara because on the east side the worst erosion occurs. The dimensions of the submerged breakwater building are placed at a depth of 3.5 meters with a building length of 50 meters, a building width of 2 meters and a building height of 2.5 meters with a gap of 10 meters as many as four modules. This building is parallel to the depth contour on the east side of Panjang Island waters, Jepara

\section{Conflict of Interest}

The authors declare no conflict of interest.

\section{Acknowledgment}

We would like thank to Oceanography Department Diponegoro University, Center for Coastal Rehabilitation and Disaster Mitigation Studies (CoRem-PKMBRP) - Center of Excellence Science and Technology (PUI), LPPM Diponegoro University and Ministry of Research Technology and Higher Education (RistekDikti) Republic of Indonesia for funding our research, with grant number 385-26/UN7.P4.3/PP/2019

\section{References}

[1] Cruz, J. 2008. Ocean Wave Energy : Current Status and Future Perspectives. Springer-Verlag, Berlin Heidelberg.

[2] Aziz, M. Furqon. 2006. Gerak Air di Laut.Jurnal Oseana, VolumeXXXI (4) : $9-21$.

[3] Dijkstra, H.A. 2008. Dynamical Oceanography. Springer-Verlag, Berlin Heidelberg.

[4] Van der Meer, J.W., 1991, Stability and Transmission at Low Crested Structures", Delft Hydraulics Publication No. 453.

[5] Pina, G.G. and J.M. Valdes F. Alarcon, 1990, Experiments on Coastal Protection Submerged Breakwaters: A Way to Look at the Results, Proc. of the 22nd Coastal Engineering Conf., Delft, the Netherlands, pp.1592-1605.

[6] Durgappa H.R., 2008, "Coastal Protection Works", Proceedings of COPEDEC VII, Dubai, UAE.

[7] Pilarczyk, K.W. 2003, "Design of Low Crested (Submerged) Structures- an Overview”, Proceedings of COPEDEC VI, Colombo, Sri Lanka.

[8] Kularatne S.R., J.W. Kamphuis, and M.A. Dabees, 2008, "Morphodynamics Around Low Crested Breakwaters - a Numerical Study", Proceedings of COPEDEC VII, Dubai, UAE.

[9] Sugianto, Denny Nugroho, Muhammad Zainuri, Alfin Darari, Suripin, Suseno Darsono, dan Nur Yuwono. 2007. Wave Height Forecasting Using Measurement Wind Speed Distribution Equation in Java Sea, Indonesia. International Journal of Civil Engineering and Technology (IJCIET), Volume 8 (9), 749-760.

[10] Holthuijsen, L. H., 2007, Wave in oceanic and coastal Waters, New York: Cambridge University Press.

[11] Triatmodjo. 1999.TeknikPantai. Beta Offset, Yogyakarta.

[12] Al Ghifari, Khalid Haidar. 2018. Studi Pola Pasang Surut Arus Musim Peralihan II Di Perairan Pulau Panjang, Jepara. 